\title{
Bibliometric analysis of research in the field of organizational communication in the web of science database
}

\author{
Web of science veritabanında örgütsel iletişim alanında yapılan \\ araştırmaların bibliyometrik analizi
}

\author{
Abdullah Türk ${ }^{1}$ \\ Kağan Cenk Mizrak²
}

\begin{abstract}
${ }^{1}$ Asst. Prof. Dr, School of Civil Aviation, Istanbul Bilgi University, Istanbul, Turkey, abdullah.turk@bilgi.edu.tr
\end{abstract}

ORCID: 0000-0002-2804-4203

${ }^{2}$ Asst. Prof. Dr, Civil Aviation Vocational School, Uşak University, Uşak, Turkey, kagancenkmizrak@gmail.com

ORCID: 0000-0003-4447-2141

\section{Corresponding Author:}

Abdullah Türk,

School of Civil Aviation, Istanbul Bilgi University, Istanbul, Turkey, abdullah.turk@bilgi.edu.tr

Revised: 4/06/2021

Accepted: 10/06/2021

Online Published: 25/09/2021

Citation: Türk, A., \& Mizrak, K.C., Bibliometric analysis of research in the field of organizational communication in the web of science database, bmij (2021) 9 (3): 1173-1185, doi: https://doi.org/10.15295/bmij.v9i3.1832

\begin{abstract}
For organizations, communication is one of the most critical factors affecting their continuity, goals, and success levels. Organizational communication directs the relationship between internal and external stakeholders of the organization by taking a role in all organizational action and managerial processes. In this context, it also affects organizational outcomes. Effectively and efficiently channelling intra-organizational communication for organizational success is also effective in employees' understanding of their duties and responsibilities within the organization and activating their knowledge skills and abilities in line with the organisation's goals. At this point, it can be said that organizational communication adds mobility to businesses through self-expression. From this perspective, it understands the communication subject's development processes that play a crucial role for organizations in the literature and revealing its relationship with other variables will bring a systematic and holistic perspective to the relevant literature. With the bibliometric analysis method made for this purpose, it is aimed to create a perspective on how organizational communication offers mobility to businesses, the development, quality and quantity of the process. In this context; Distribution of studies on organizational communication by years, co-authorship of authors, coauthorship of organizations, co-authorship of countries, citation of authors, bibliographic coupling of documents, co-citation of authorship, co-citation of sources, co- The maps of occurrence of keywords were created, and the levels of contribution to the literature and the areas where the subject interacts were conveyed.
\end{abstract}

Keywords: Organization, Communication, Organizational Communication, Bibliometric Analysis, VOSviewer

Jel Codes: O15, O19, M12

\section{Öz}

Genel olarak örgütler için iletişim konusu devamlılıklarını sağlama, amaçlara ulaşma ve başarı düzeylerini etkileyen en önemli faktörlerden biridir. Örgütsel iletişim, tüm örgütsel eylem ve yönetimsel süreçlerde rol alarak örgütün iç ve dış paydaşları arasındaki ilişkiyi yönlendirmektedir. $\mathrm{Bu}$ bağlamda örgütsel çıktıları da etkilemektedir. Örgütsel başarı için örgüt içi iletişimi etkin ve verimli bir şekilde kanalize etmek çalışanların örgüt içindeki görev ve sorumluluklarını anlamalarını, bilgi beceri ve yeteneklerini örgütün amaçları doğrultusunda harekete geçirmelerinde de etkili olmaktadır. Bu noktada örgütsel iletişimin işletmelere kendisini ifade edebilme üzerinden hareket kabiliyeti kattığı söylenebilir. Bu bakış açısıyla örgütler için kilit rol oynayan iletişim konusunun literatürde gelişim süreçlerini anlayabilmek, diğer değişkenlerle ilişkisini ortaya koyabilmek, ilgili yazına sistematik ve bütüncül bir bakış açısı kazandıracaktır. Bu amaçla yapılmış olan bibliyometrik analiz yöntemi ile örgütsel iletişimin işletmelere hangi açılarla hareket kabiliyeti sunduğu, sürecin gelişimi, niteliği ve niceliğine dair bir perspektif oluşturmak amaçlanmıştır. Bu bağlamda; örgütsel iletişim konusunda yapılan çalışmaların yıllara göre dağılımı, co-authorship of authors, co-authorship of organiations, co-authorship of countries, citation of authors, bibliographic coupling of documents, co-citation of authorship, co-citation of sources, co-occurence of keywords haritaları oluşturulmuş ve literatüre katkı düzeyleri, konunun etkileşim içinde olduğu alanlar aktarılmıştır.

Anahtar Kelimeler: Örgüt, İletişim, Örgütsel İletişim, Bibliyometrik Analiz, VOSviewer

JEL Kodları: O15, O19, M12 


\section{Introduction}

Communication is defined as creating, sharing and exchanging feelings, thoughts and information, at the point of being active, reflective and healing when people perform their duties in the organization. Mwankwo (2003) defines communication as the interaction between individuals or groups. Communication is the connection of parts of a system to serve a holistic purpose. Communication enables people to develop and share knowledge, combine efforts and expand their knowledge, technology and culture warehouses to achieve the best results in organizational outputs (Ayeni and Akinola, 2020; 95). Organizations; the distribution of duties and managers guides employees to achieve the organisation's final goals (Kilıçarslan, 2016; 156). Situations taking place in the organization are not independent of each other. At this point, organizational communication can be defined as the exchange of information, feelings and thoughts that employees realize in line with common goals and objectives among individuals in the organization (Tutar \& Yilmaz, 2013; 21).

Communication is an essential element for developing organizations. An organization that does not create an effective communication environment will find it challenging to achieve its goals. Organizational communication is a form of activity performed by people involved in an organization. Communication within organizations is divided into external communication and internal communication (Kristina, 2020; 67). Organizational communication; It provides the coordination of the organization in its relations with its internal and external stakeholders (Tanrıverdi, Adıgüzel ve Çiftçi, 2010), the harmony within the organization, the walking of the works and the motivation in the management and production processes (Solmaz, 2004; 108). The organizational communication process is not unidirectional and includes feedback as a result of organizational actions. The communication process without feedback is not healthy. In the organizational communication process, the interaction between employee and manager occurs in two directions (Kurudayığlu \& Deniz, 2001). Organizational communication; Planning, coordination, motivation and control functions are carried out in two ways depending on the structural characteristics of the communication and the flow direction of the message. Depending on the structural feature, formal and informal communication, vertical communication depends on the message's flow direction; It appears top-down, bottom-up, horizontal, and crosses communication (Genç, 2004). Thanks to this communication, managers can provide the necessary information exchange in decision-making processes. It is essential for managers to convey their decisions to employees and to mobilize employees. It positively affects the job satisfaction and motivation of the employees and indirectly their organizational commitment. It is essential to ensure the continuity of organizational activities and cooperation between employees, reducing the margin of error, reducing costs, and profitability in the effective execution of strategic plans (Bakan \& Büyükbeşe, 2004). No matter how skilled and high-performance employees are, they cannot turn into potential performance if there is no effective communication in the organization. Effective communication in organizations plays a significant role in the effectiveness and efficiency of the organization (Gökçe, 2006; 87). As a result of the multi-faceted effects and results of organizational communication, the studies conducted in the literature between 2000 and 2021 were researched with bibliometric analysis to create a systematic perspective. Studies on organizational communication were scanned; The authors, journals, institutions, countries, organizational communication, the development process, which variables are related to the literature, which subjects were studied and not studied were determined and mapped. Another aim is to provide a qualitative and quantitative perspective to researchers who will work in the future.

\section{Literature review}

\section{Communication}

People can understand and explain their inner and outer worlds through communication. With the help of communication, people transfer feelings, thoughts and information to their environment and make sense of it (Çakır, 2020). In this context, the communication process within the organization means much more than the daily conversations of the employees. Communication plays a vital role in fulfilling the duties and responsibilities of the employees in the organization. Managers provide coordination by reaching their employees through the communication function. As a result, the work can be done more efficiently by ensuring employee integrity (Çetinkaya and Akkoca, 2021: 74-75). The nature of communication is an idea, emotion, thought, any positive or negative organic behaviour. Therefore, communication; has a different character according to the environment in which it is located, the people in this environment and the structure of relations. It can be said that it represents different mobility in every environment where communication exists. Contact; Although it is one of the essential elements for industrial efficiency in the business literature, it comes to the fore. However, the basics of 
communication convey the social reflections of cultural codes. At this point, the basis of social behaviour processes, which reflect culture, gains meaning with the necessity of reconciliation.

Thanks to the continuity of change, the dynamics of an organization that is constantly developing point to unified organizational communication. The transfer of culture, which is already like organizations, is also provided through communication. At this point, organizational communication; is one of the most important elements desired for the organization to achieve its final goals. (Kristina,2020:62).

\section{Organizational communication}

Organizational communication is defined as the use of all communication tools to establish effective communication by evaluating the communication environment within the organization as a whole. In addition, organizational communication is a process that ensures the continuous exchange of information and the creation of interdepartmental relations in order for the organization to achieve its goals. Sharing information and ideas within the organization plays a role in creating a positive working environment (Kaplanseren and Nart,2020: 920). Sharing information and ideas within the organization plays a role in creating a positive working environment (Kaplanseren and Nart,2020: 920). Therefore, organizational communication reflects the organisation's basic principles, culture, characteristics, values , and orientation (Suh, Harrington \& Goodman, 2018: 223). When we look at the studies done in domestic and foreign literature, positive relations between organizational communication and positive psychological capital, citizenship, self-employment, organizational commitment, and internal productivity support variables come to the fore.

The primary purpose of organizational communication is to contribute to the organization by acting in cooperation. This contribution is made by supporting the employees in realising organizational goals by providing the most appropriate communication channel. Organizations also have purposes such as influencing and directing people in parallel with the objectives determined according to their nature (Oğuzhan, 2020; 17). Contact; An architectural task is assumed in harmonising the social structure to ensure coordination and integrity.

\section{Methodology}

Bibliometry; It covers the mathematical and statistical analysis of data obtained from sources such as articles, books, and journals (Broadus, 1987). Bibliometric analysis; It is accepted as an interdisciplinary basis that provides a broader perspective by mapping the development level of scientific studies (Khara et al., 2020). Bibliometric studies make it possible to quantify a specific field by reviewing the literature and evaluating the results, determining the variables associated with the field (Kasemodel et al., 2016) and identifying the missing points (Van Raan, 2005). The techniques used in the analysis have evolved. The contributions of the publications in the literature to the scientific field started to be analyzed based on institution, country, and author (Okuba, 1997; 9). Bibliometric analysis data; It was taken from the Web of Science database, a scientific reference and statistical information platform that provides comprehensive and comprehensive data in various fields of knowledge (Li et al., 2018). Analyzing the citations made in the studies provides data to determine the sources that contribute the most to the field, the history of the literature in the relevant fields, and the leading journal (Tatar \& Ece, 2012; 1). The data were mapped by analyzing the emergence of countries, institutions, co-authors, journals and keywords with the VOSviewer analysis program (Omoregbe et al., 2020).

In this study, all studies conducted between specific years in the relevant field using the Web of Science database were scanned and documented to evaluate the contributions made to the literature. Documented studies were transferred to the VOSviewer database and visualized. The data transferred to the VOSviewer database, co-authorship of authors, organizations, countries, citation of authors, bibliographic coupling, co-citation of authors, sources, co-occurrence of keywords maps were created. Created maps; It enabled the visualization of authorship, co-authorship, institution, country, bibliographic data, citation analysis and the variables associated with the keyword formation map.

It can be seen that bibliometric analysis provides benefits such as revealing the chronological development performance of the field, providing mobility to the literature, providing qualitative information along with quantitative information about the studies, presenting the variables studied and not studied in the field, providing a perspective by guiding future studies with current information.

\section{Findings}


In the web of science database, 1,398 studies were found as the topic of "organizational communication" and published between 2000-2021. The distribution of the studies conducted over the years is shown in Table 1.

Table 1: Distribution by Years

\begin{tabular}{|c|c|}
\hline Publication Year & Publication Number \\
\hline 2021 & 18 \\
\hline 2020 & 138 \\
\hline 2019 & 141 \\
\hline 2018 & 124 \\
\hline 2017 & 129 \\
\hline 2016 & 146 \\
\hline 2015 & 120 \\
\hline 2014 & 54 \\
\hline 2013 & 66 \\
\hline 2012 & 65 \\
\hline 2011 & 66 \\
\hline 2010 & 51 \\
\hline 2009 & 49 \\
\hline 2008 & 47 \\
\hline 2007 & 38 \\
\hline 2006 & 30 \\
\hline 2005 & 27 \\
\hline 2004 & 17 \\
\hline 2003 & 12 \\
\hline 2002 & 17 \\
\hline 2001 & 15 \\
\hline 2000 & 20 \\
\hline & \\
\hline & \\
\hline
\end{tabular}

Considering the distribution of the work done by years; Between 2000 and 2007, it has been observed that the work done in the field of "organizational communication" around the world is at a minimal level. An average streak was caught between 2007 and 2014. Especially as of 2015, the number of studies gained momentum, which reached the highest level in 2016. Since the number in 2021 covers the first half of the year, it does not represent the whole year. When a general evaluation is made; It is seen that 816 studies conducted in the last six years constitute approximately $59 \%$ of the total 1,398 studies conducted in the last 21 years. When the subject of organizational communication gained momentum; It seemed to coincide with the period when social media, smartphones and mass media encouraged a subjective collective network for each individual, organization and industry. This situation can be evaluated as expanding the scale of globalization and the effect of rapid internationalization, where everyone can see each other on the scale of academic work.

In Figure 1, studies on "organizational communication" between 2000 and 2021 were scanned in the Web of Science database, and it was seen that a total of 2652 authors contributed. It is seen that the number of those who published at least 3 of these authors is 111 . Co-authoring connection strength with other authors was calculated for each of these researchers. It was seen that 64 authors from these researchers were linked to each other. Especially Fajardo Valencia and Gloria Consuelo formed the most significant cluster with the most connections, 28 streams and 28 connection strengths. Nivia Florez and Adriana Marcela formed another largest cluster with 28 publications and 28 connectivity. Cooren and Francois formed the second-largest cluster with 19 broadcasts and 23 connection strengths. Leonardi, Paul M. formed the third cluster with nine broadcasts and 12 connection strengths. Buzzonell and Patrice M. formed the fourth cluster with 13 streams and seven connection power. According to these data, connection strength and co-authorship numbers show how vital collective power is in academic studies. In addition, the connections of prominent researchers with each other and their rankings highlight how important the network is in academic studies. It shows that the linking power of this synergy is also essential for its qualitative contribution to academic studies. 


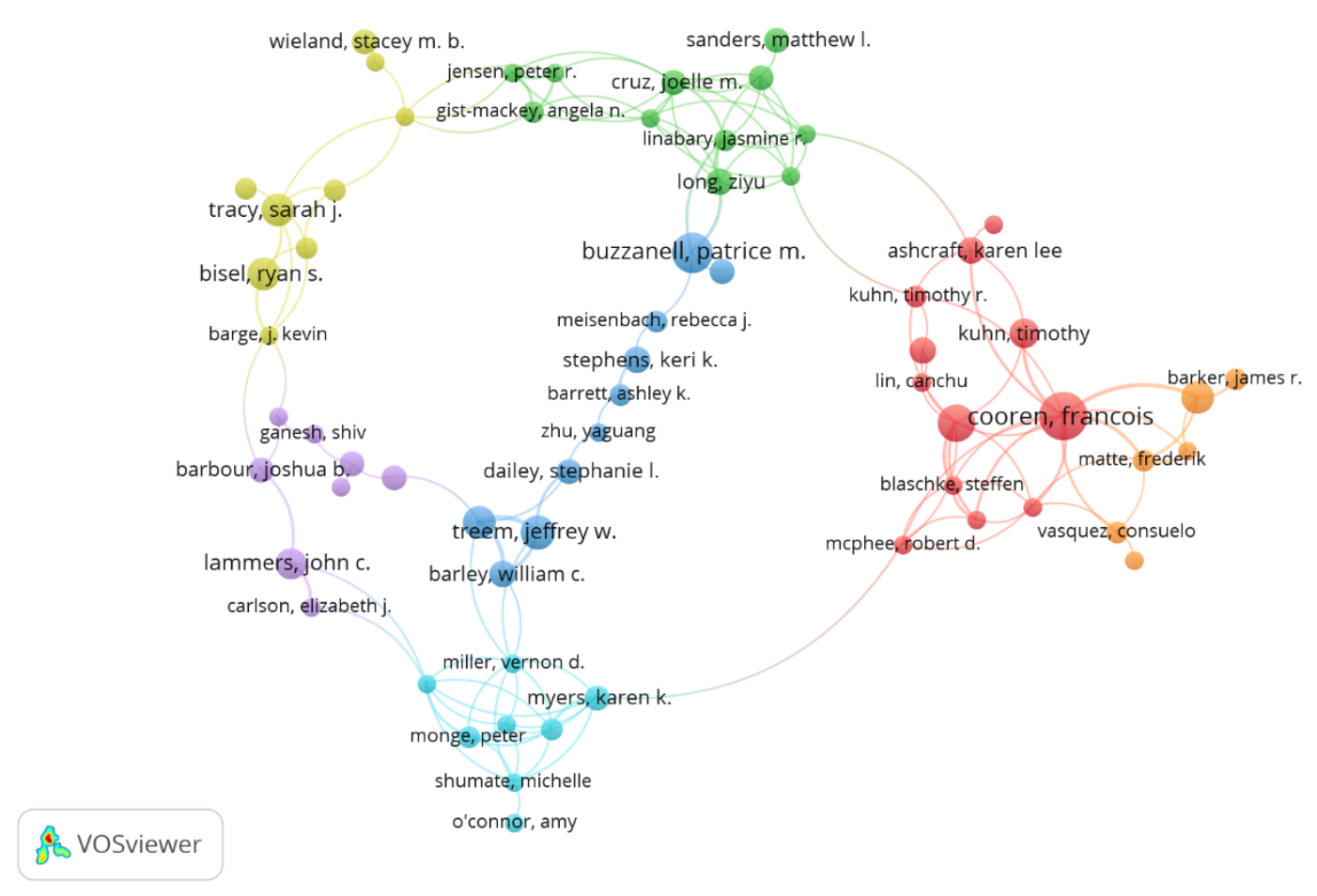

Figure 1: Co-authorship of Authors on Organizational Communication

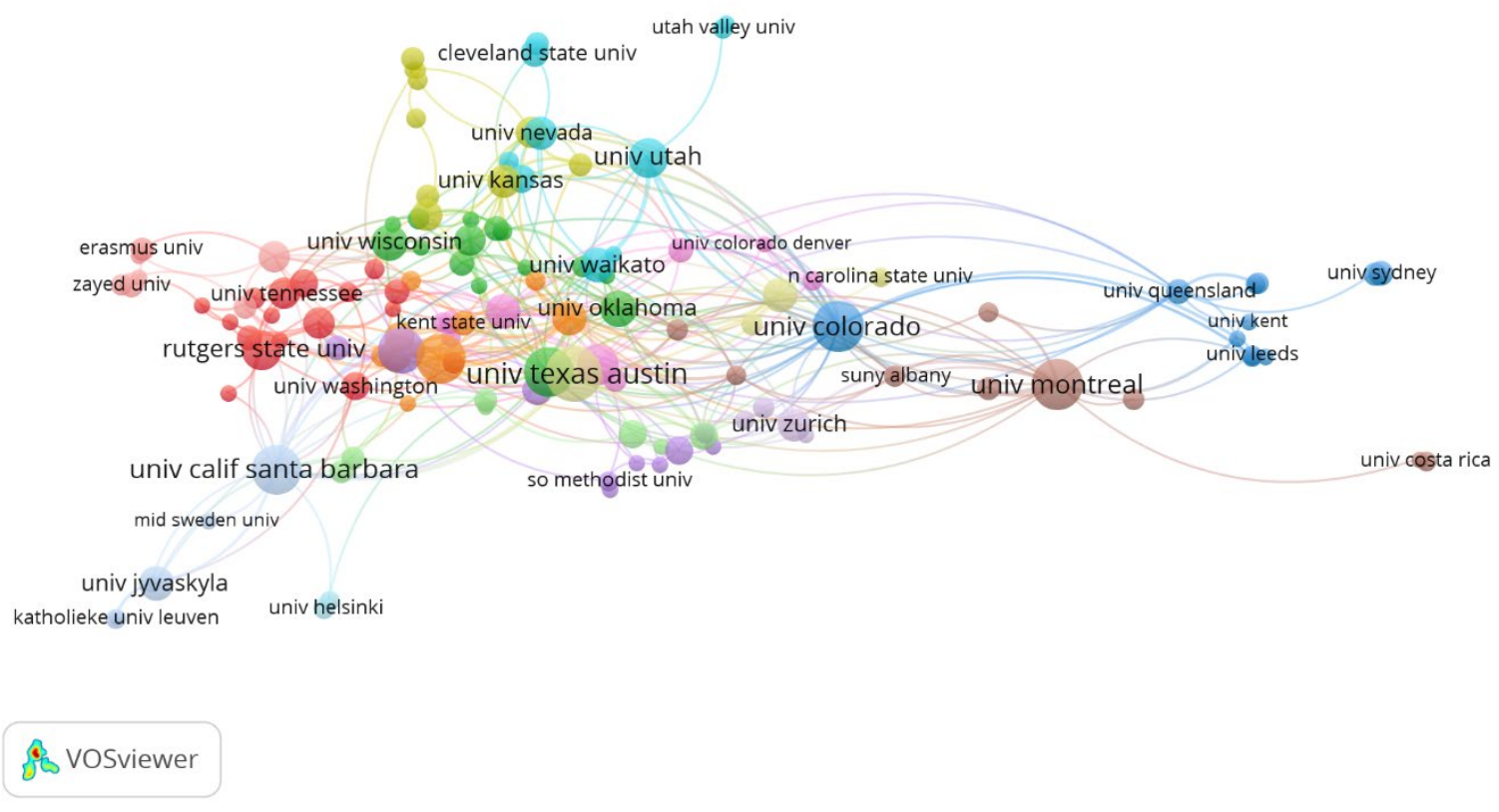

Figure 2: Co-authorship of Organizations on Organizational Communication

In Figure 2, studies on "organizational communication" between 2000 and 2021 were scanned in the Web of Science database, and a total of 1150 organizations were found. Of these organizations, 176 institutions have published at least three publications. In addition, a co-authorship connection with other organizations was determined for each of the organizations. It has been determined that 133 out of 176 organizations are interconnected. Of these, Indiana University received 1060 citations in total with five publications. The University of Colorado has published 27 publications and received a total of 1055 citations. The University of Utah has published 17 publications and received 939 citations. The fourth most cited university was the University of Montreal, with 27 publications, with 866 citations. Purdue University has published 25 publications and received a total of 404 citations. The University of 
Missouri published 13 publications and received 169 citations in total. Another data given by the coauthorship of organizations map is related to the connectivity of universities. Accordingly, the universities with the most connection power are the University of Colorado with 40 connectivity, Texas Austin with 34 connectivity, Purdue University and the University of Missouri with 31 connectivity. According to the transferred data, academic studies' general idea is a connection power parallel to the number of studies. However, in this data, a contrary picture emerges. The most important conclusion to be drawn from this is that the qualifications of the studies carried out by institutions or individuals are independent of quantitative data.

In Figure 3, studies on "organizational communication" between 2000 and 2021 were scanned in the Web of Science database, and a total of 71 countries were identified. It has been determined that at least three publications have been made in 51 of these countries. In addition, a common citation link with other countries was calculated for each of these 51 countries. According to this calculation, 47 of 51 countries seem to be interconnected. According to the data given by the co-authorship of countries map, the number of publications is; USA 657, Canada 53 publications, England 40 publications, Australia 39 publications, Netherlands 33 publications, Denmark 24 publications. Another data given by this map is the citation ranking; USA 14016 citations, Canada 1339 citations, England 1232 citations, Denmark 891 citations, Australia 815 citations, Netherlands 698 citations. The only conclusion to be drawn from this is that it is in the 6th place in the publication ranking and the 4th place in the citation ranking in Denmark, which may create a perspective on the quality of the publications among the quantitative data for this country. In addition, the effect of the synergy created with the network of the researchers, whose result is shown in Figure 1, is also seen in the interaction with the countries. Therefore, the consistency of the data transferred in figures 1 and 3 comes to the fore.

象 Vosviewer

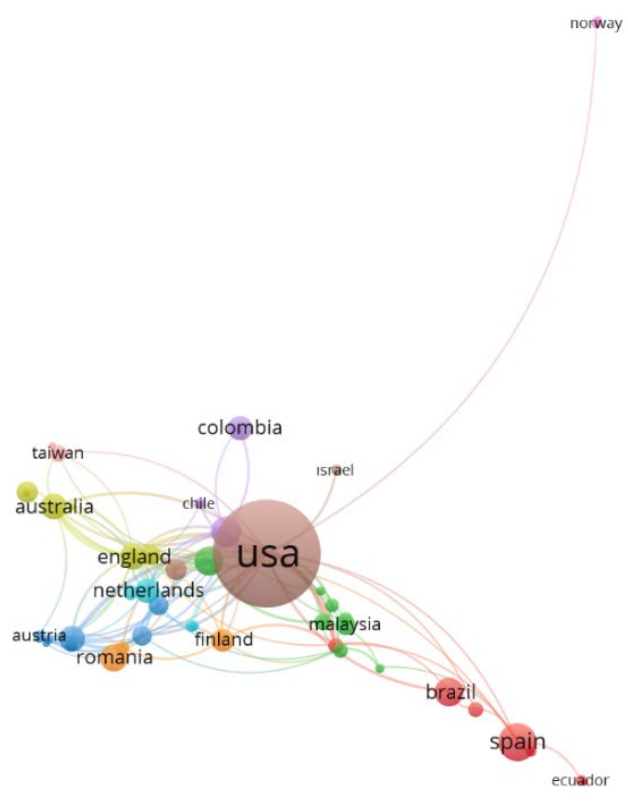

Figure 3: Co-authorship of Countries on Organizational Communication 


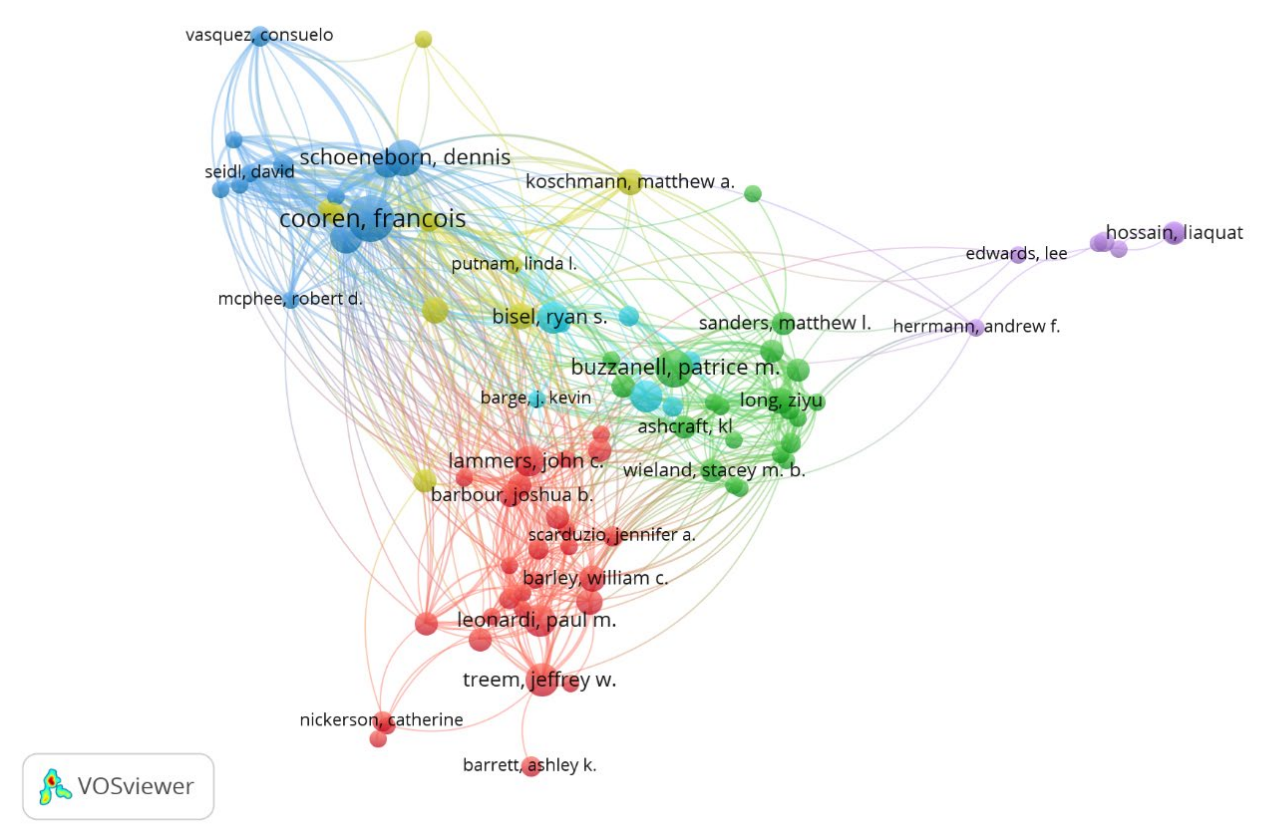

Figure 4: Citation of Authors on Organizational Communication

In Figure 4, studies on "organizational communication" between 2000-2021 were scanned in the Web of Science database. The number of citations with other authors was calculated for each author from the data obtained in this map. According to this; The number of citations of the researchers who contributed to their studies as a single author is listed. Cooren, Francois ranks first with 19 publications and 820 citations in total. Then Saxton, Gregory D. 4 publications and 613 citations, Ashcraft, Karen Lee 6 publications with 530 citations, Kuhn, Timothy R. 4 publications and 470 citations, Lars Thoger Christensen made three publications and 424 citations, Dennis Schoenebon with 12 publications. It received 355 citations. After this ranking, the ranking continues with a significant decrease in publications and citations made. The practical conclusion to be drawn from this is that as the number of publications decreases, researchers with more citations than other authors can express a qualitative meaning and quantitative data. At this point, contrary to the general opinion in academic studies, there is no direct proportion between quality and quantity. This study data shows consistency in the name of the study in parallel with the data interpretation given in Figure 2.

duan(2017)

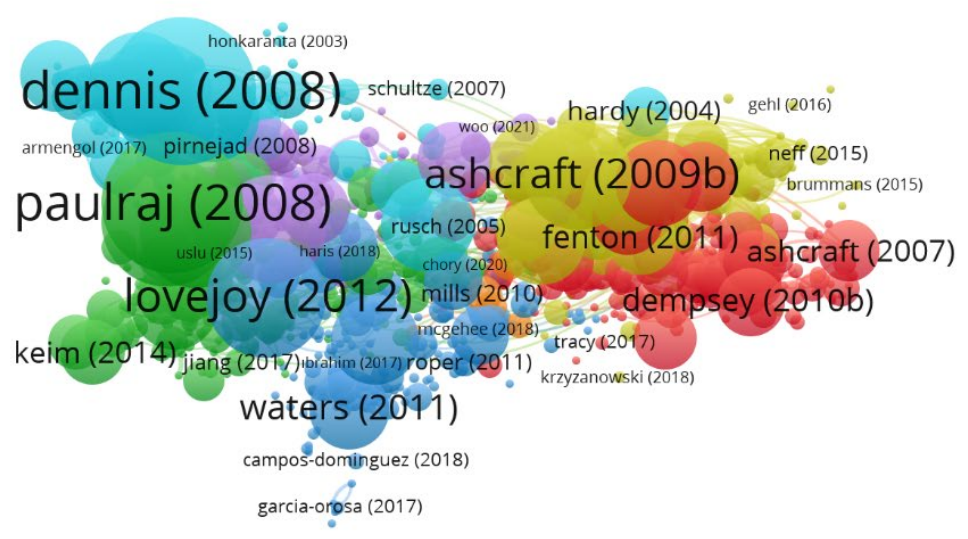

VOSviewer

Figure 5: Bibliographic Coupling of Documents Organizational Communication 
In Figure 5, between 2000-2021, 1398 studies of "organizational communication" were found in the Web of Science database. 998 of 1398 studies were found to be interconnected. The finding obtained from this map determines the year in which the highest citation was obtained for a single study and which journal was published. According to this, Dennis, Alan R .; Fuller Robert M .; Valacich Joseph S. made the most significant cluster with 567 citations to their work in Mis Quarterly in 2008. Paulraj, Antony and Lado, Augustine A. and Chen, Injazz J. 519 to their work in the Journal of Operations Management in 2008, Johnston, Allen C. and Warkentin, Merrill to 433 citations to their publication in Mis Quarterly in 2010, Lovejoy, Kristen and Saxton Gregory D., on the other hand, received 376 citations to his publication in the Journal of Computer-Mediated Communication in 2012, Aschkraft, Karen Lee and Kuhn, Timothy R. and Cooren, Francois received 302 citations for their work at the Academy of Management Annals in 2009. After this ranking, the years show similarity, and the number of citations decreases in a balanced way. The practical conclusion that can be drawn shows that the highest reference to a single work in organizational communication was received in 2008. In addition, when evaluated based on Table 1, it may be because the first year, the number of stable publications caught in the relevant article coincided with this year. It is seen that the power of the works given collectively is more than the efficiency obtained from the works done alone. It also shows that a single study with multiple authors can have a more substantial qualitative power than studies with one author. These data also support the data obtained from figures 1 and 3, emphasising the importance of networking in academic studies. The practical conclusion to be drawn from here is; In academic studies, it is seen that connection, citation, country pairing, author association are factors that increase the quality.

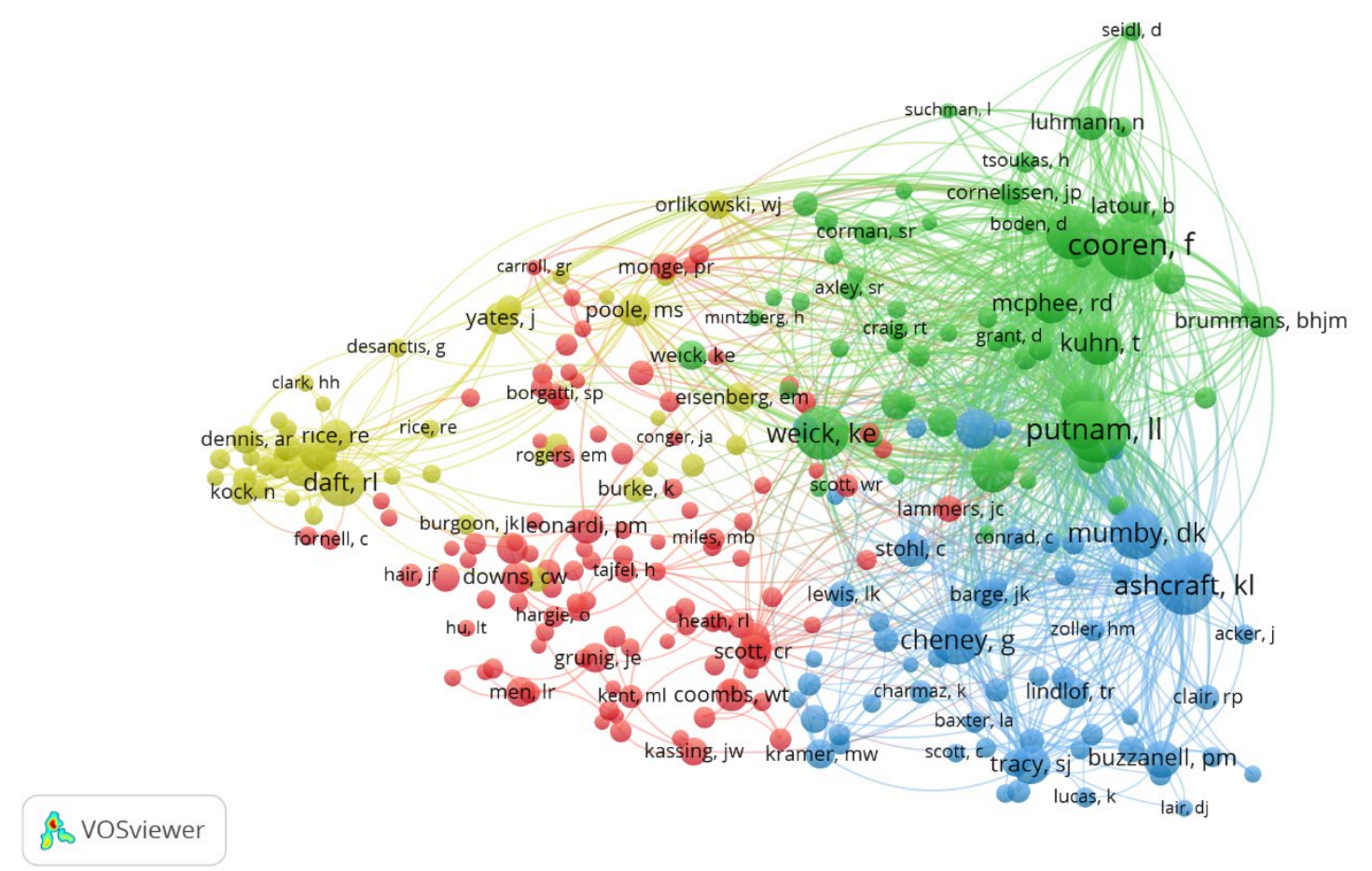

Figure 6: Co-citation of Authorship on Organizational Communication

In Figure 6, in the Web of Science database, 269 authors were identified when the evaluation was made within a minimum of 20 citation constraints among 2652 authors who worked on "organizational communication" between 2000 and 2021. The number of joint citations for more than one study of the same author with other writers was calculated in this map, according to this; Cooren, F. 345 citation, Putnam, L.L. 288 citations, Ashcraft, K.L. 258 citations, Taylor, J.R. 228 citations, Weick, K.E. 219 citations, Mumby D.K. It received 210 citations, Cheney, G. 194 citations. As of this ranking, 100 households are ranked with a steady decrease. This research data needs to look at the table in reverse while revealing the author's character on organizational communication. At this point, the number of authors with 20 or fewer citations is 2,383. This data shows that $90 \%$ of the authors working on organizational communication have a severe deficiency in producing quality works in the field. In other words, $90 \%$ of the authors should increase the quality of their studies in this field.

In Figure 7, When all publications on "organizational communication" and organizational communication were evaluated in the Web of Science database between 2000-2021, within a minimum of 20 citations, 363 journals were identified. For each of these journals, the total number of citations of 
the studies in the relevant field was calculated, according to this; "Academy of Management Review" 986 references, "Academy of Management Journal" 834 references, "Organization Sciences" 821 references, "Management Communication Quarterly" 682 references. The "Administrative Science Quarterly" received 676 references. "Communication Monographs" received 655 citations. The practical conclusion to be drawn here is that the number of publications in each journal may take different quantitative ranges. However, when these quantitative data are evaluated alone, it may be misleading in determining the qualified contribution to the relevant field. While contributing to the journal's quality that it publishes, the number of citations received in the relevant field can create a more robust perspective. The obtained research data offers researchers who want to work in this field about journals or institutions that publish qualified works in the relevant literature.

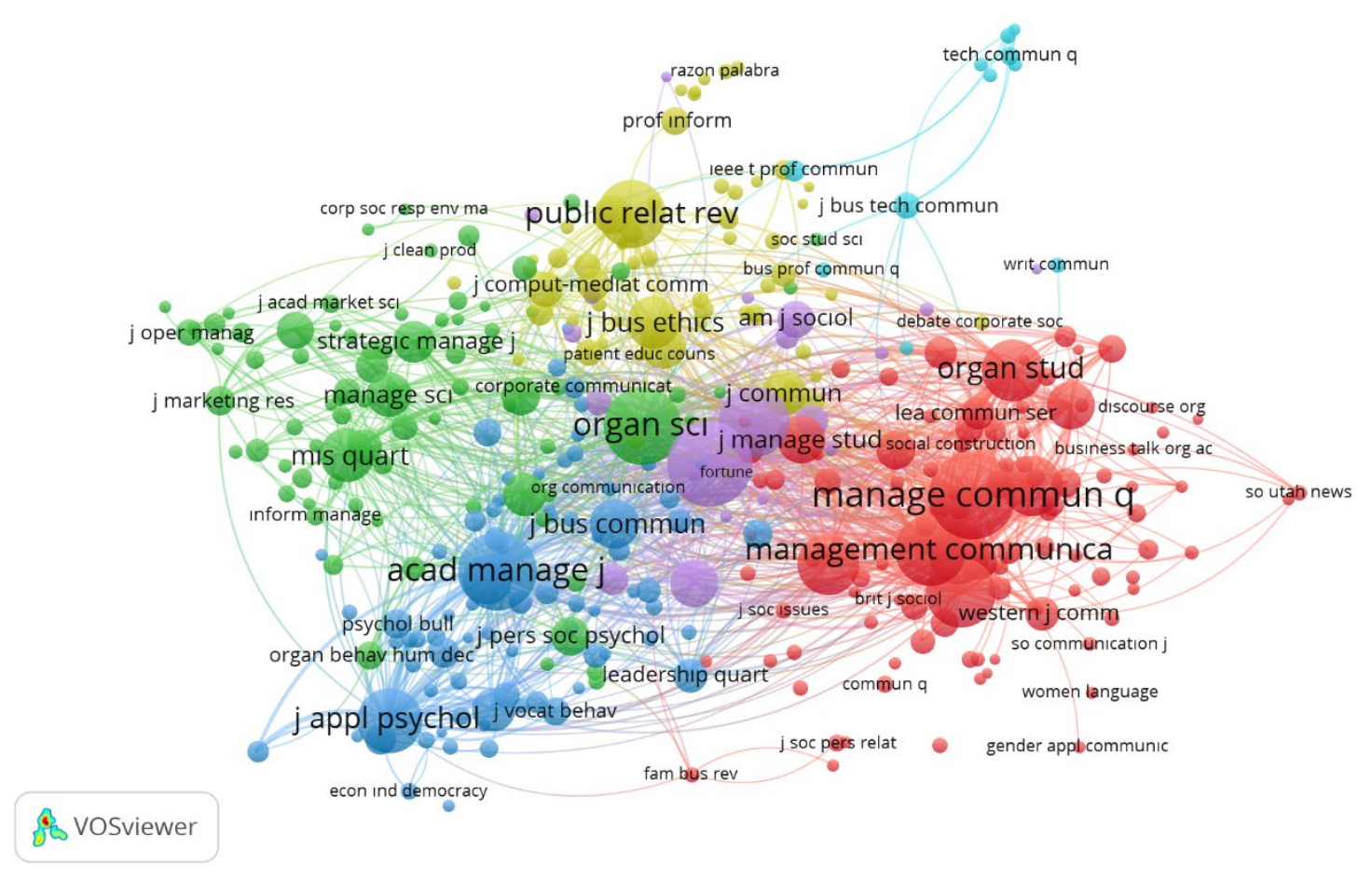

Figure 7: Co-citation of Sources on Organizational Communication

A total of 3298 keywords were found in the studies on "organizational communication" between 2000 and 2021 in the Web of Science database. When the found keywords are evaluated within the minimum ten repetition constraints, 40 keywords have been identified. According to this; "Organizational communication" 515 times, "communication" 103 times, "public relations" 51 times, "social media" 46, "organizational culture" 30 times, "corporate communication" 29, "internal communication" 27 times, "leadership" 26 "corporate social responsibility" and "social networks" were used 20 times, "job satisfaction" 17 times, "sensemaking" 16 times. A practical conclusion to be drawn here; shows which variables are in a more intense relationship with the relevant subject. This data can also provide a perspective for researchers who want to work on the relevant subject to make different contributions to the literature. 


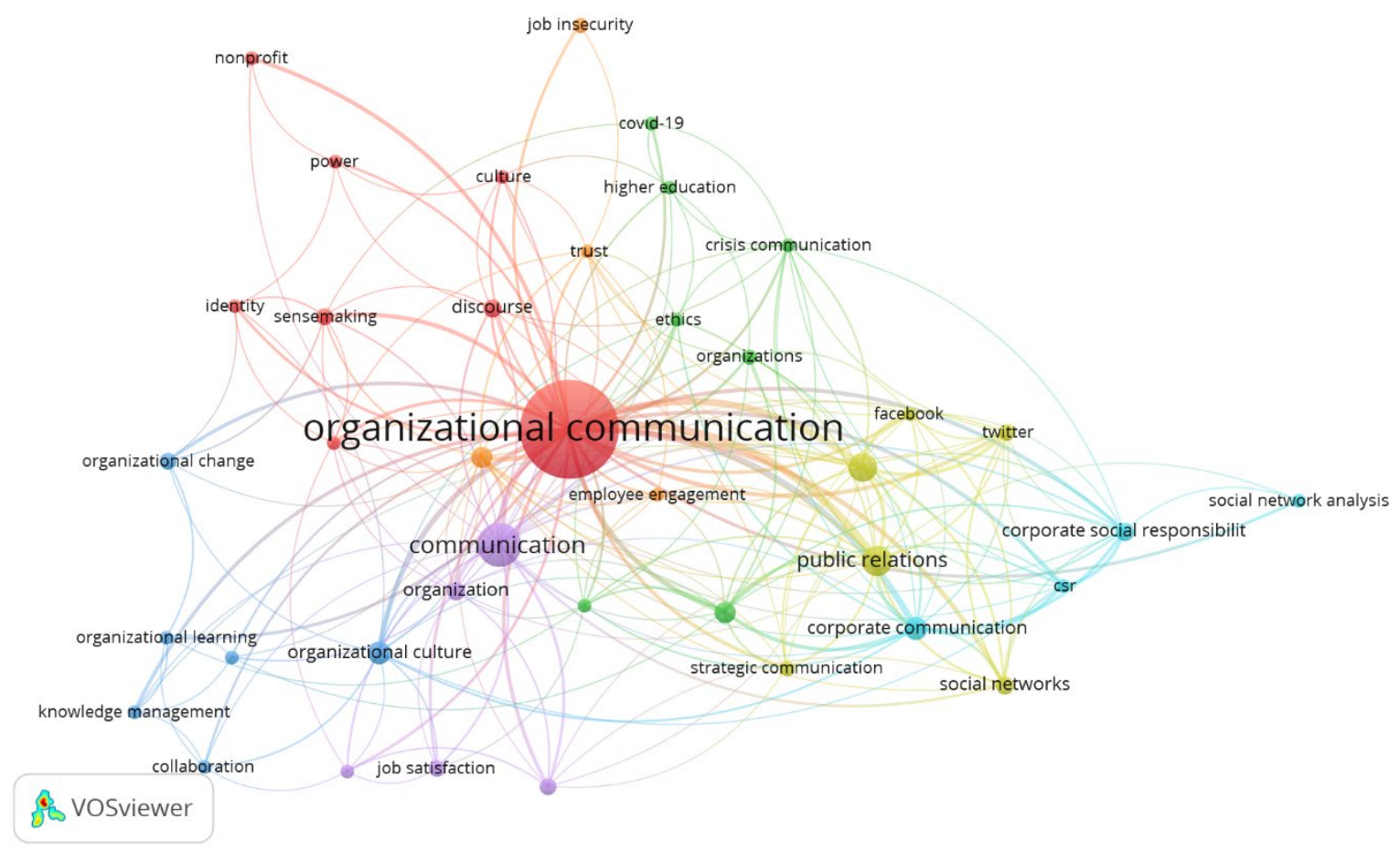

Figure 8: Co-occurrence of Keywords on Organizational Communication

\section{Conclusion}

The relationship network is revealed by the mapping method of bibliometric analysis; By creating a qualitative perspective besides quantitative information, it provides information about the development of the relevant subject and the level of development over time and the performance level of the subject. From this point of view, the development speed of the organizational communication subject, whose bibliometric analysis is made, has been tried to create a perspective for the quantitative aspect and, therefore, quality. In particular, data such as citation analysis, co-authorship, the most citations to a single study, the most citations to more than one study, the contribution of the institutions and organizations that made the publications, and the word cloud that constitutes a perspective on which other variables studied in the relevant field were compiled and evaluated. The most commonly used keywords, as shown in Figure 8; organizational communication, communication, public relations, social media, organizational culture, corporate communication, internal communication, leadership, corporate social responsibility, social networks, job satisfaction, sensemaking. Based on these results; When the general field assessment was made, it was seen that it created mobility of literature in human resources management, organizational behaviour, corporate communication. When evaluated more specifically, it is understood that the area where it works the most after intra-organizational communication is related to public relations, which is an external stakeholder for the company. The practical conclusion to be drawn from this may be the importance of the business's point of view to make a profit. In addition, the fact that social media is the second area of study frequently reveals the interest focused on new platforms where communication with customers is established within the current field of work as a reflection of the digital transformation era. Organizational communication is closely related to the institution's culture, as it is intensely related to organizational processes. Another relationship density of bibliometric analysis made on organizational communication gave quantitative data related to organizational culture. These data show that organizational communication plays a decisive role in organizational processes. Another result is related to the intensity of leadership work. The relationship of these two areas with each other shows the necessity to direct corporate processes, manage people in a network of relationships, and take a leading role in the organization. Because leadership includes the ability to direct and manage human relations in line with the goals determined by the relationship channels within the organizational process. The nature of organizational communication is movement. However, this movement requires the obligation to comply with the workflow plans that must be managed and directed. For this reason, organizations should act in the awareness that they need to fulfil their responsibilities at a sufficient level and at the right time to their 
stakeholders in a certain network of relationships. This judgment confirms both the relationship of leadership practices with communication and the frequency of corporate social responsibility and corporate relationship network studied on the subject. The dimension of interpersonal relations in the relevant subject constitutes the communication network of the organization in total. The more versatile this dimension is, the stronger the network of relationships. The intensity of vertical or horizontal coordination in a work environment is important in completing the works. One of the important outcomes of this factor is that employees feel satisfied with their work. The frequency of studies conducted between organizational communication and job satisfaction creates a perspective on the importance of relationship coordination for businesses. In organizational communication, not all information transferred within the network is in open information format. Most of the time, this information is in implicit format. At this point, the process of perceiving the information given in the communication network occurs. The quality of communication directly affects the speed of the perceived process. Conducting studies between organizational communication and sensemaking confirms this situation. Especially, studies conducted in this area create more than one perspective and highlight striking points. This study conducted in the field of organizational communication has two general presentations about the literature. The first of these points out the importance of organizational communication with external stakeholders, although it is related to internal processes. The other points out that this network is manageable, especially considering the relationship between the processes in the communication network and the issue of leadership. At this point, it is seen that this study in organizational communication has achieved its purpose. Especially in recent years, the increase in research in organizational communication shows an increase in interest in this field. As a result of the findings, the countries that contributed the most to the literature with their institutions and co-author networks in this field are the USA, Canada, England, Australia, Netherlands, Denmark. However, especially in Turkey, qualified studies in the relevant field could not be determined. It is thought that the most important limitation of this situation may be about foreign languages when the related literature is developed in the countries. In order to increase the quality in terms of the country, the journals in which the qualified works are given, the countries that give the qualified works, the authors who produce the qualified works should be followed systematically. However, as there is an increase in the number of studies in organizational communication that point to the communication processes between internal and external stakeholders of the organization, the literature will deepen. Therefore, another suggestion is important to guide the researchers who will work in the related field with the frequency of other variables transferred with the co-occurrence keywords map and work with different variables that have not been studied to diversify the related literature of quantity and quality.

\section{Peer-review:}

Externally peer-reviewed

\section{Conflict of interests:}

The author(s) has (have) no conflict of interest to declare.

\section{Grant Support:}

The authors declared that this study has received no financial support

\section{Ethics Committee Approval:}

This study does not require ethics committee approval.

\section{Author Contributions:}

Idea/Concept/Design: A.T. Data Collection and/or Processing: A.T. Analysis and/or Interpretation: A.T. Literature Review: K.C.M. Writing the Article: A.T., K.C.M. Critical Review: A.T., K.C.M. Approval: A.T., K.C.M.

\section{References}


Ayeni, A. J., \& Akinola, O. B. (2020). Organizational Communication and Teachers' Productivity in Secondary Schools in Ondo State, Nigeria. Revista Journal of Education and Practice, 11(17), 94-102.

Bakan, İ. ve Büyükbeşe, T. (2004). “Örgütsel İletişim ile İş Tatmini Unsurları Arasındaki İlişkiler: Akademik Örgütler için Bir Alan Araştırması", Akdeniz İ̈BF Dergisi, 7, 1-30.

Broadus R. N. (1987). Toward a Definition of "Bibliometrics", Scientometrics, 12 (5-6): 373-379.

Çakır, M. (2020). Örgütlerde iletişim sorunlarının saptanması ve çözümü için kullanılabilecek teknikler üzerine bir inceleme, İşletme Araştırmaları Dergisi, 12 (1), 973-989.

Çetinkaya, F. F., \& Akkoca, Y. Stratejik Liderlik İle Örgütsel Çeviklik Arasındaki İlişkide Örgütsel İletişimin Aracı Rolü. Mehmet Akif Ersoy Üniversitesi İktisadi ve İdari Bilimler Fakültesi Dergisi, 8(1), 66-84.

Genç, N. (2004). Yönetim Organizasyon, Ankara: Seçkin Yayınları.

Gökçe, O. (2006). İletişim Bilimine Giriş. Ankara: Siyasal Kitabevi.

Kaplanseren, S., \& Nart, S. (2020). Psikolojik Güçlendirme Ve Presenteeism İlişkisinde Örgütsel İletişimin Aracılık Etkisi: Y Kuşağı Çalışanlarına Yönelik Bir Araştırma. Journal of Administrative Sciences/Yonetim Bilimleri Dergisi, 18(38).

Kasemodel, M. G. C., Makishi, F., Souza, R. C. ve Silva, V. L. (2016).“Following the trail of crumbs: A bibliometric study on consumer behavior in the Food Science and Technology field", International Journal of Food Studies, 5(1):73-83

Khara, B., Dey, J. K., \& Mondal, S. K., (2020). Sustainable recycling in an imperfect production system with acceptance quality level dependent development cost and demand. Computers \& Industrial Engineering, 142, 106300.

Kılıçarslan, S. (2016). İletişime Giriş. Ankara: Seçkin Yayınları.

Kristina, K. (2020). The Organizational Communication Perspective Theory. Journal of Social Science, 1(3), 61-74.

Kurudayığlu, M. ve Deniz, K. (2001). İletişim. Ankara: Gazi Üniversitesi.

Li, K., Rollins, J. ve Yan, E. (2018). Web of science use in published research and review papers 19972017: A selective, dynamic, cross-domain, content-based analysis. Scientometrics, 115, 1-20.

Oğuzhan, M. (2020). Kamuda Örgütsel İletişim Sorunsalı: E-Devlet'e Kısa Bir Bakış.

Okuba, Y. (1997), "Bibliometric Indicators and Analysis of Research Systems: Methods and Examples", OECD Science, Technology and Industry Working Papers, 1997/01, OECD Publishing, (http://dx.doi.org/10.1787/208277770603).

Omoregbe, O., Naseer, A., Steinberger, M. R., El-Kharouf, W. A. \& H. Onyeaka. (2020). Carbon capture technologies for climate change mitigation: A bibliometric analysis of the scientific discourse during 1998-2018. Energy Reports. Volume 6, November 2020, Pages 1200-1212.

Solmaz, B. (2004). Kurumsal Söylenti ve Dedikodu Türkiye'deki İşletmeler Üzerine Bir Uygulama. Konya: Tablet Kitapevi.

Suh, J., Harrington, J., \& Goodman, D. (2018). Understanding the link between organizational communication and innovation: An examination of public, nonprofit, and for-profit organizations in South Korea. Public Personnel Management, 47(2), 217-244.

Tanrıverdi, H. \& Adıgüzel, O. ve Çiftçi, M. (2010). “Sağlık Yöneticilerine Ait İletişim Becerilerinin Çalışan Performansına Etkileri: Kamu Hastanesi Örneği". Süleyman Demirel Üniversitesi Sosyal Bilimler Enstitüsü Dergisi. Sayı:11, 101-122.

Tatar, C.C. \& Ece, A. S. (2012). Bilimsel Dergilerdeki Müzik Makalelerinin Bibliyometrik Profili. Akademik Bakış-Uluslararası Hakemli Sosyal Bilimler Dergisi, (30), 1-16.

Tutar, H. \& Yılmaz, M. K. (2013). İletişim Genel ve Örgütsel Boyutuyla. Ankara: Seçkin Yayıncılık.

Van Raan, A. F. J. (2005). Fatal Attraction: Conceptual and Methodological Problems in the Ranking of Universities by Bibliometric Methods.Scientometrics, 62(1), 133-143.

Yılmaz, B. (2003). "Toplumsal İletişim ve Kütüphane", Hacettepe Üniversitesi Edebiyat Fakültesi Dergisi, 20(2), s.11-29. 
